
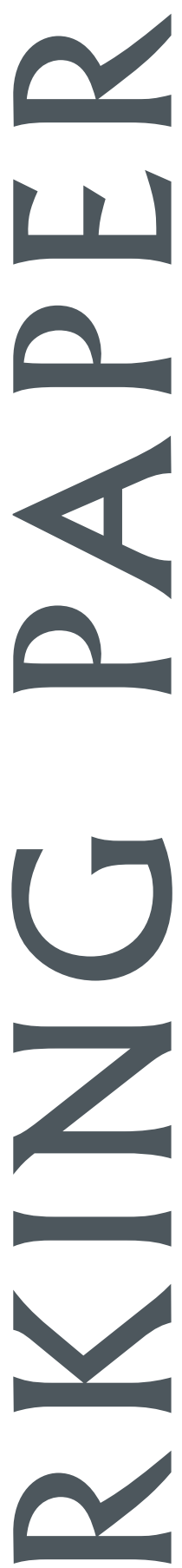

EAST-WEST CENTER 
The U.S. Congress established the East-West Center in 1960 to foster mutual understanding and cooperation among the governments and peoples of the Asia Pacific region including the United States. Funding for the Center comes from the U.S. government with additional support provided by private agencies, individuals, corporations, and Asian and Pacific governments.

East-West Center Working Papers are circulated for comment and to inform interested colleagues about work in progress at the Center.

For more information about the Center or to order publications, contact:

Publication Sales Office

East-West Center

1601 East-West Road

Honolulu, Hawaii 96848-1601

Telephone: 808-944-7145

Facsimile: 808-944-7376

Email: ewcbooks@EastWestCenter.org

Website: www.EastWestCenter.org 


\title{
Global Production Networks and Information Technology: The Case of Taiwan
}

\author{
Shin-Horng Chen
}

Shin-Horng Chen is the Deputy Director of the International Division, Chung-Hua Institution for Economic Research.

This paper will appear in Industry and Innovation, Vol. 9 No. 2 (August), Special Issue, "Global Production Networks, Information Technology and Local Capabilities." Dieter Ernst and Linsu Kim (guest editors).

East-West Center Working Papers: Economics Series is an unreviewed and unedited prepublication series reporting on research in progress. The views expressed are those of the author and not necessarily those of the Center. Please direct orders and requests to the East-West Center's Publication Sales Office. The price for Working Papers is $\$ 3.00$ each plus postage. For surface mail, add $\$ 3.00$ for the first title plus $\$ 0.75$ for each additional title or copy sent in the same shipment. For airmail within the U.S. and its territories, add $\$ 4.00$ for the first title plus $\$ 0.75$ for each additional title or copy in the same shipment. For airmail elsewhere, add $\$ 7.00$ for the first title plus $\$ 4.00$ for each additional title or copy in the same shipment. 


\section{Introduction}

Ever since the 1980s, the information industry has increasingly become the engine of economic growth in Taiwan; however, whilst progressive development of the information sector is being widely experienced throughout the world, Taiwan's information industry has outgrown the majority of its international counterparts. On a worldwide scale, Taiwan currently ranks as the third largest producer of information products and Taiwan's characteristic feature of local industrial clustering has already been well-documented (Hobday, 1995; Kim and Tunzelmann, 1998; Kraemer, et al., 1996). Nevertheless, it is becoming increasingly evident that globalization is reshaping the way in which the information industry is organized globally, consequently, local agglomeration can no longer adequately account for the dynamics of Taiwan's information industry. Rather, it is global production networks that have come to the fore. This has something to do with the changing strategies of brand marketers, particularly in the US. In response to this, information product manufacturers in Taiwan have 'gone global' to deploy their production networks - and more recently logistics networks - so as to maintain their cost efficiency in order to better serve their customers.

Similarly, from its inception, the development of Taiwan's IC industry was driven by a strategy of vertical disintegration, which in turn, facilitated the formation of local and cross-border linkages as the momentum for industrial expansion. Moreover, the emergence of system-on-a-chip (SOC - to be further explained below) will probably lead to further vertical disintegration within the industry. This will give rise to the important question of how Taiwanese firms manage to ensure their inter-organizational and cross-border linkages function so smoothly. An obvious explanation lies in the application 
of information technology (IT) because it enables real-time information flows and functional coordination across organizational and national boundaries.

We therefore find ourselves with two sets of interrelated questions. First of all, what are the features of the global production networks in which the Taiwanese firms are involved; and how do these Taiwanese firms position themselves within the global production networks in order to acquire market niches and indispensable capabilities? Secondly, in what way can IT be used to facilitate Taiwanese firms' participation in the global production networks; and how can IT strengthen these Taiwanese firms' position within these networks? This paper sets out to explore these issues in the context of industrial structure and its effects on inter-firm relationships.

The analysis proceeds in four stages. First of all, taking into account the features of certain technologies and globalization, Section 2 discusses the importance of inter-firm linkages and the emergence of global production and knowledge networks. The role of IT in global production networks is also discussed briefly. Section 3 undertakes an analysis of the way in which IT production and application interact within global networks, followed in Section 4 by an examination of the personal computer (PC) and integrated chip (IC) industries. Each section incorporates an in-depth case study as a means of elaborating on the points made. Finally, Section 5 concludes the paper with an examination of the potential implications.

\section{Globalization and the Development of Global Production Networks}

In a departure from the standard economic theory with its tendency to portray firms as vertically integrated, cross-country industries are increasingly linking up along the value chain and across industrial boundaries. On the one hand, the standard economic theory, to a 
certain extent, has failed to capture the complexity of industrial organization, whilst on the other hand, the cross-border linkage of firms has increasingly arisen largely as a direct result of globalization. In order to elaborate on our first point, it is useful to refer to Schumpeter's discussion on the relationship between technological innovation and industrial organization. Widely publicized is Schumpeter's concept of 'creative destruction', which tends to champion the cause of small technological firms or innovative entrepreneurs in challenging both large established firms and existing technologies based on radical technological breakthroughs. In contrast to the above 'Mark I' scenario, Schumpeter (1942) recognized that established firms may be in a better position to appropriate new knowledge by means of devices such as patents, secrecy, lead times and superior sales efforts. As a result, there is a 'Mark II' scenario that is characterized by high market concentration and the continuing existence of large established firms.

However, the Mark I/Mark II analysis fails to capture the complexity of technology and its effects on industrial structure, particularly in the area of IT. As argued by Windrum (1999), innovations such as e-commerce involve technical systems that are inherently large, comprising of a set of jointly-consumed interdependent products. Because of network effects and product compatibility, successful innovations for technical systems entail intensive interfaces between multiple actors with different knowledge and skills bases, termed as 'innovation networks'. By implication, not only does such innovation often result from the collective efforts of inter-related firms, but it also demonstrates that the value chain does not need to be completely internalized within individual firms. Therefore, in many cases, industrial competition takes place between rival technological and production networks that contain a multiplicity of differentiated firms, rather than between vertically integrated oligopolists. However, the relevant literature tends to focus mainly on 
innovation networks woven by firms in the advanced countries (for example Delapierre and Mytelka, 1998), whilst downplaying the role played by firms in countries such as Taiwan.

In addition, the trend towards globalization is reshaping the landscape of industrial competition. One aspect of globalization over the last few decades has been the increasing disintegration of capabilities in production, and even innovation, across nations (Freenstra, 1998). Driven by this disintegration, the outreach of multinationals takes the form not only of direct investment, but also outsourcing of production, and even knowledge. As a result, boundaries between firms have become blurred on an international scale (Delapierre and Mytelka, 1998), which has eroded the basis for the formation of traditional oligopolies. Instead, industrial rivalry now tends to occur amongst industrial networks comprising of a multiplicity of firms linked up with different knowledge bases. Although the driving seat is occupied mainly by well-established firms in the advanced nations of the world, firms in countries such as Taiwan also have a role to play.

Against this background, offshore sourcing is increasingly being adopted by many American firms - and more recently by Japanese firms - in their efforts to come to terms with the new global industrial dynamics (Chen and Ku, 2000; Kotabe, 1996; Swamidass and Kotabe, 1993; Venkatesan, 1992). In this regard, many brand marketers tend to concentrate their core competencies on brand name resources and $\mathrm{R} \& \mathrm{D}$, whilst outsourcing the remainder of the value chain. As a result, having traditionally been considered as vertically integrated multinationals, they are increasingly becoming hollowing-out corporations (Kotabe, 1989).

On the other hand, a new breed of multinationals has emerged, such as Contract Electronics Manufacturers (CEMs). CEM companies, unlike the more traditional 
manufacturers and multinationals, do not make their own brand name products, deploying instead global networks with fast-response capabilities to provide production and other (mainly logistics) services to brand marketers. By the same token, Taiwan's PC industry has evolved from a local production network towards a global one.

In a comparison with the PC industry, global production networks may mean something different for the IC industry; nevertheless, the essence remains the same. By disintegrating the IC value chain, the initial emergence of foundry services in Taiwan facilitated the proliferation of small- and medium-sized firms engaged in other market segments, such as IC design, testing and packaging, leading to a vertically disintegrated industrial structure. Moreover, the emergence of SOC has induced the modularization of various design technologies, known as silicon intellectual properties (SIPs), which can be used repetitively as the main building block for SOC. This trend has given rise to 'chipless' IC firms, acting as pure providers of SIP without owning a fab, or even a chip, leading to further disintegration of the industry (TSMC, 2000). As a result, IC design and production has come to resemble SIP assembly (see Appendix Figure 1).

Although most SIPs are owned by integrated device manufacturers (IDMs), fabless firms - and increasingly, chipless foundry service providers - are the natural places to verify the value and 'fabricability' of SIPs. Therefore, in order to go through the entire value chain, the industry is required to bring together a variety of industry players, including chipless firms, design service providers, IC designers, electronic design aid (EDA) tool providers and foundry and packaging firms, who are likely to be located across nations. The production networks in the industry are hence global, or at least international, in nature.

We then come to the question of the role of IT in these global production networks. IT 
can be considered as an innovation of 'transaction' technology, which can facilitate intraand inter-organizational value chain management in a real-time and cost effective manner (Economist Intelligence Unit, 2000). The use of IT in conjunction with the reshuffling of business models can help firms to achieve speed and flexibility in an industry where time is critical (Kraemer, et al., 2000). In this regard, IT is more than a transaction facilitator, and in fact, is promoted as being an enabling technology for collaborative commerce amongst firms, involving not only inter-organizational coordination of the supply chain but also cooperation in product definition, design and R\&D (Berryman and Heck, 2001). In this way, production networks in the 'bricks and mortar' world may be transformed into virtual supply networks and collaborative communities. This is not to suggest that industrial advantages derived from the physical world will become dispensable, but rather, as will be shown below, that they can go hand in hand with IT applications to bolster the prospects of the firms involved.

\section{Global Logistics and IT - The PC Industry}

In 1999, Taiwan was the world's third largest producer of PC-related products, with a significant number of Taiwanese-made products such as motherboards, scanners, monitors and notebook computers, enjoying a healthy global market share. Taiwan's characteristic local industrial clusters and their role in the growth of the PC industry in Taiwan have been well scrutinized (Hobday, 1995; Kawakami, 1996; Kraemer et al., 1996), but local agglomeration alone can no longer adequately account for the dynamics of Taiwan's PC industry, because whilst global production networks have come to the fore, the way in which the global PC industry is organised has changed.

In this regard, an important milestone in the development of Taiwan's PC industry was 
the outreach achieved by local firms starting from the late 1980s. Their outward investment was initially directed towards Southeast Asia, but more recently towards mainland China and elsewhere in the world. The offshore production of Taiwan-based PC firms grew from US\$973 million in 1992 to US\$18.86 billion in 1999 , which at that time, represented 47.29 percent of total production. It follows that the volume of export orders received by local firms has increasingly diverged from their actual exports. According to our observations, the divergence widened significantly in 1997, which had to do with the changing role of Taiwanese firms in the global production network (Chen and M.C. Liu, 2000).

The PC industry's drive towards the reduction of lead-time to market, along with lower production and inventory costs, brought about a profound change in the manufacturing system and inter-firm competition within the industry. It became commonplace for components to be sourced from a global network of suppliers and for final assembly to be undertaken in the end-market (Angel and Engstrom, 1995; Borrus and Borrus, 1997). More specifically, major brand marketers moved to adopt outsourcing and order-based production, which greatly rationalised their global supply chain, hence altering their contractual relationships with Taiwanese firms. Compaq, for example, pioneered the so-called 'optimized distribution model' which, in essence, was aimed at allowing customers to choose what they wanted, when and how, at the lowest prices. There are three facets to this operational model. Firstly, in order to narrow the gap between supply and demand, production must be 'build-to-order' (BTO), based on meeting orders, rather than forecasts. Secondly, in order to meet the wide variety of consumer demands, producers must not only build-to-order but also configure-to-order, making customised products in specific quantities. Thirdly, vendors must undertake final assembly, bringing together a set of subassemblies produced and delivered by subcontractors. Compaq imposes a '98-3' 
operation formula on subcontractors, requiring them to collect 98 percent of the components and parts needed for production within 3 days of the order and to ship the product within six days of receipt of the order.

Such contractual arrangements with global leaders in the PC industry prompted Taiwanese IT firms to upgrade their position within the global production system and these firms have subsequently taken on the essential functions of coordinating the global supply chain for their OEM customers. For example, under its new business model, Compaq outsourced every element of the value chain, with the exception of marketing, to Taiwanese subcontractors. By so doing, the company completely handed over its inventory costs to these subcontractors, who were also required to produce and deliver sub-system products on tight schedules and in tune with the vagaries of market demand. The Taiwanese firms had to ensure that everything was synchronised up and down the supply chain and in order to do this they had to participate in cross-border supply-chain management, logistics operations and after-sales services, coordinating all of these functions through the formation of a fast-response global production and logistics network or 'global logistics' (Chen and Liu 1999; Schive 2000). A case study on Mitac is presented below in order to elaborate on these points.

Mitac International Corporation is one of Taiwan's leading PC manufacturing services companies, producing over 10 million PCs in 2000, and accounting for around 8 per cent of global production. In the latest issue of Forbes, Mitac was recognized as the 495th largest company in the world, as compared to 607 th in 1999 , achieving revenues of US\$5.274 billion in 2000. According to the company, its "current remarkable performance can be attributed to long-term efforts in areas such as supply chain management, global logistics, vertically integrated manufacturing services, as well as aggressive adoption of e-commerce and 
other Internet-based mechanisms to enhance operational efficiency and create new business opportunities". The firm now maintains manufacturing/assembly sites in Taiwan, mainland China, the US, Japan, Belgium and the UK.

Mitac's strategic restructuring, with a global logistics and e-commerce flavor, started from the early 1990s; however, during 1992 and 1993, the company suffered serious deficits because of the oversupply of PC components and parts. Underlying this was the inflexibility of the then system-integrated production under one roof in Taiwan, leading to overstocking. In response, Mitac pioneered the Modulus Manufacturing System under which the PC, as a system, was divided into different moduli to enable fast-food style production, the ultimate purpose being 'build-to-order' (BTO). Its partnership with Compaq, a global leading brand-name marketer, has facilitated Mitac's large-scale deployment of global logistics and e-commerce.

Mitac has placed significant effort into reconfiguring its international production and logistics network in order to serve Compaq's global operations (see Appendix Figure 2). In 1998, Mitac began setting up a materials hub in Hsinchu, Taiwan, within which its main production site is located. This materials hub stocks parts and components for producing barebones, mainly from its own suppliers, who have to bear inventory and warehousing costs before Mitac gives a green light for delivery for production. As soon as all the parts and components arrive at the production site, they are manufactured into barebones, which are then immediately shipped, normally by sea, to overseas assembly sites. As a result of this process, Mitac substantially reduces its inventory risks, whilst its suppliers, in return, get better payment terms and swifter financing services from Mitac.

In an effort to meet Compaq's configure-to-order practices, Mitac has also set up a number of configuration hubs close to its overseas assembly sites located in major 
international market areas. These configuration hubs serve to stock key and price-sensitive parts and components such as CPUs and RAMs. The overseas assembly sites undertake the final assembly function, bringing together barebones delivered from Mitac's manufacturing sites and key parts and components from configuration hubs. Compaq dominates the operation of the configuration hubs, using its bargaining power to gain better prices for the key parts and components.

In addition, Mitac has established a few fulfillment centers in the major market areas in order to broaden its value chain. Since price competition has intensified and profit margins have narrowed for most mature PC products, Mitac can no longer act as a pure manufacturer to sustain its long-term development. By setting up the fulfillment centers, Mitac has begun to shoulder the responsibility for after-sales services for Compaq. The returns are not only financial, but also technical, because it has helped Mitac to gain direct feedback for its product designs and production.

However, these fulfillment centers are likely to be reduced to after-sales service outposts, functioning simply to replace out-of-order parts and components, as Mitac has already started to build up a large-scale repair and maintenance plant in mainland China. This will help Mitac to utilize the cheap labor available in China without sacrificing the quality of its after-sales services and the technical gains already noted.

Such contractual arrangements also entail progressive deployment of e-commerce links between Mitac and its vertical and horizontal counterparts. In fact, it was Compaq's requirement of 'no electronic data interchange (EDI), no order' that prompted Mitac to embark upon the application of e-commerce. Moreover, a governmental initiative aimed at promoting e-commerce links between Taiwanese firms and their international customers 
(known as the TaiWeb Project in Compaq's case) ${ }^{1}$ has facilitated the electronic links between Compaq and Mitac (as well as a few other Taiwanese firms) migrating in part from an EDI-base to an Internet-base.

By means of EDI, Mitac is electronically linked with Compaq and its own suppliers. Sales forecasts from Compaq are transmitted to Mitac periodically with weekly adjustments, termed as a 'rolling plan'. On this basis, Mitac puts forwards its own manufacturing plans, inventory buffering and stock level requirements to its suppliers. Following these information flows, Mitac's international production and logistics networks, mentioned above, assume their role in meeting tight production and delivery schedules and the variety of market demands. The second phase of the TaiWeb Project (known as the 'B Plan' Project) will extend the e-commerce applications of all the parties involved from supply chain management to other transaction-related activities such as payment and warranty services. In addition, Mitac is to develop a 'virtual' materials hub mechanism over the Internet. The ultimate purpose is to get rid of physical warehouses, eliminating inventory costs on both sides of the transaction. This has to be based on strong mutual trust and commitment between Mitac and its suppliers.

Mitac has also set up a Collaborative Product Commerce (CPC) mechanism for online joint product design. It incorporates an intra-link that enables all the parties involved to use the same design tools for joint product design and development, ranging from product definition, to product $R \& D$ and product modularization. This not only helps to reduce the R\&D cycle time for Mitac and its partners, it is also essential to the coordination of the production, assembly, delivery and repair and maintenance activities that follow.

\footnotetext{
1 The TaiWeb Project is a Compaq-centric e-supply chain project, which incorporates advanced and open technology, supply chain processes and applications. It involves Taiwanese suppliers such as Mitac, Arima, foxconn, Inventec, Quanta, ADI, Compal, Delta and Lite-on and represents Compaq's first rollout to partners in the Asia-Pacific region.
} 
Although driven by brand-named marketers (such as Compaq), Mitac has now electronically linked both its inter-firm and intra-firm value-chain activities. Over the electronics network, multilateral and timely information flows and sharing has, on balance, been greatly enhanced, facilitating effective synchronization both up and down the inter-organizational and international supply chain. By so doing, Mitac and its partners are now involved in design collaboration, commodity management, supplier rationalization and supply collaboration which strengthen not only their transaction efficiency but also their learning and innovative capabilities.

A significant change brought about by the global logistics practice, or more specifically, BTO, is the substantial increase in the frequency of ordering and hence rising speed of delivery. In the past, it took 40 to 60 days for PC firms to go through the entire transaction process, from order to delivery. Under BTO, however, subcontractors such as Mitac, have to meet a tightened schedule of 5 to 7 days, or even 2 to 3 days. In addition, patchy production, instead of mass production, has become the dominant practice. Modular manufacturing and IT networking is hence indispensable to Mitac's formation of a rapid-response global production and logistics network. From Taiwan's perspective, the essence of this development is that local IT firms, like Mitac, are transforming from stand-alone OEM manufacturers, into providers of integrated service packages encompassing a wide range of value-chain activities.

This development is particularly significant in terms of an often-neglected aspect of high-technology manufacturing. High-technology manufacturing industries, like the PC industry, are widely regarded as high value-added; however, they tend to be vulnerable to accelerating competition and narrowing profit margins even before reaching the mature stage of the product life cycle because of the rapid changes in technology. As a result, firms 
and nations that rely heavily on high-technology hardware manufacturing can be easily caught up in deteriorating trading terms. In addition, most of Taiwan's IT firms undertake OEM/ODM contract works, without any strong ability to control, or even gain direct access to, the final market. Their outreach, by means of moving elements of their manufacturing and/or assembly functions overseas, implies that they have to generate additional profits through the widening of their value chains. In the case of global logistics, they have begun to shoulder service functions such as the coordination of cross-border supply chain and logistics, in addition to their initial manufacturing function. It is therefore arguable that they have looked beyond manufacturing profits to seek profits from the services they provide to brand-name marketers. In fact, a study by the Central Bank in Taiwan reveals that global logistics contracting contributed $0.85 \%$ to Taiwan's GDP growth in 1999.

Furthermore, central to global logistics is the subcontractors' ability to weave together the cross-national constituent elements of the value chain into a competitively effective and rapidly responsive production and logistics system. This means that they are engaged in the rules of the game that industrial competition in the PC industry relies not merely on cheaper costs, but more on rapid response capabilities and flexibility. Although Taiwanese IT firms are not in the driving seat, they have proved themselves capable of taking part in setting up the rules of the game. Therefore, with a global production and logistics network at their disposal that is capable of satisfactorily meeting the needs of their customers, Taiwan-based IT firms may preempt the entry into the network of their counterparts in many countries. As a result, from Taiwan's point of view, many of the owners of world-class PC brand names, which are international core firms in the industry, can be 'anchored' to Taiwan's economy (Chen and D. Liu, 2000). 
Substantial performance improvements have also been made on the part of Mitac. For example, Mitac's inventory turnover rate increased from 3.53 in 1993 to 12.71 in 1998. At the same time, immediately after its materials and configurations hubs were set up, its inventory cycle time was reduced substantially from 103.4 days to 30 days. The company also managed to achieve Compaq's 95-5 operation formula targets in 1997 and is well on the way to the next milestone, the 98-3 operation formula targets.

The Mitac experience shows that global logistics and e-commerce need to be accompanied by a reshuffling of the business model so that it can come to terms with the local firm's position in the international industrial network and industrial dynamics. The business model in question needs to address both internal and external aspects of the industrial value chain. Moreover, from their own opinion, whilst reciprocity or mutual forbearance is essential to the operation of global logistics, industrial muscle with sufficient bargaining power remains indispensable to the negotiation processes involved.

\section{Vertical disintegration and Virtual Integration - The IC Industry}

Taiwan's IC industry is currently the fourth largest in the world, behind only the US, Japan and Korea, however, the industry in Taiwan differs from those of the other three in several ways. Unlike Korea, which specializes in the production of dynamic random access memory (DRAM), Taiwan produces a much wider variety of IC chips whilst also dominating in foundry services, capturing around 70 per cent of the global market share. In addition, in contrast to the vertically integrated conglomerates dominating the industry in Korea and Japan, Taiwan's IC industry consists of many small firms specialising in a narrow range of the value chain, such as IC design, mask production, foundry service, packaging and testing. In fact, Taiwan's flock of some 127 IC design houses puts it second 
only to the US in terms of the number of companies operating in this segment. In a sense, Taiwan's IC industry is organized as an industrial network system with a strong connection to Silicon Valley, the global center of IC technology and the IC market.

The author has documented elsewhere (Chen and M. Liu, 2000; Chen, Chen and Liu, 2001) that Taiwan's IC industry has, to a large extent, come to resemble the scenario of the flexible specialization thesis (Piore and Sable, 1984). In short, fabless IC design houses proliferated in Taiwan partly because access to external fabrication capacity lowered the barriers to entry into the IC design market. In addition, the concentration of IC and computer-related firms in the Hsinchu Science-Based Industrial Park generated agglomeration effects that allowed these firms to exploit the benefits of proximity and outsourcing. Therefore, even though they specialise in one segment of the value chain or another, IC firms in Taiwan are networked by social and business connections. On the other hand, it is also evident that Taiwan's IC industry is closely connected to the industry center in Silicon Valley in terms of business and knowledge linkages (ibid.). Underlying this are the trans-Pacific social and business networks (Saxenian, 1997; Kim and Tunzelmann, 1998) and the similarity of industrial structures between Silicon Valley and Hsinchu (Sanxenian, 1997).

For the purposes of this paper, the author would like to argue further that such industrial networking as exists in Taiwan's IC industry has also benefited from recent innovations in IT. Firstly, by reducing the uncertainty and transaction costs involved in purchasing from the best outsiders, IT reduces large firms' advantages of centralized purchasing and in-house suppliers. Secondly, technological changes have resulted in smaller production runs, increasing the feasibility of product changes and allowing small, specialised firms to exploit fragmented product markets on the basis of their flexible response. In addition, the 
IC industry is following the PC industry in moving rapidly towards order-based production. Leading IC firms in Taiwan are championing the concept of the 'virtual factory' by deploying the Internet and extranet to electronically link with their customers and suppliers. The case of TSMC, presented below, helps to shed light on this point.

TSMC may be regarded as a major catalyst in the abovementioned evolution of the industry. The company was created to function as a dedicated foundry service provider, simply carrying out contract fabrication work for global customers ranging from start-up ventures to world-leading IDMs. Therefore, customer relationship management, as well as fabrication capacity and capability, were always central to TSMC's operations, in which e-commerce has come to play an increasingly important role.

E-business in TSMC started in 1995 with the introduction of Total Order Management (TOM) as a tool for bridging supply and demand in fabrication, and for order and production scheduling. TSMC has also formed electronic links with its suppliers by implementing continuous replenishment programming (CRP) in order to minimize its inventory costs; however, these can only be considered as the most basic elements of TSMC's 'extended' supply chain management.

In the 'arms-length' relationship between foundries and fabless design houses, it is essential to manage the flow of knowledge so as to facilitate a smooth and efficient transfer of new designs into production. This has been made possible by the design firm's adherence to 'design rules' laid out by the foundry, namely, restrictions on the type of designs that will be manufactured in the foundry on a specific delivery schedule. These design rules are determined by the foundry's manufacturing capacity and capability. In light of this, foundries such as TSMC have become an essential node of the innovation network of new IC designs, which entails close interactions of knowledge and information 
between foundries and their customers. As a result, in 1996 TSMC initiated the concept of the 'virtual fab' in order to promote virtual integration with its customers by means of business-to-business (B2B) applications, thus rendering TSMC as the facilitator of its customers' supply chain management.

Apart from regular online business transactions, TSMC's B2B, under a total package of 'eFoundry' covers three major aspects: logistics, engineering and design collaborations (see Appendix Figure 3). TSMC's eFoundry consists of a suite of Internet-based applications providing its customers with real-time support in wafer design, engineering and logistics, functioning as the master tool for the concept of the virtual fab. It currently supports five online services, including TSMC-Online (updated to version 3.0), TSMC-Direct, TSMC-YES (Yield Enhancement System), TSMC-ILV (Internet Layout Viewer) and eJobView.

In terms of collaboration in logistics, TSMC-Online provides access to real-time production and logistics information updates in areas such as the status of wafer fabrication, assembly and testing, as well as order handling and shipping. As for engineering collaboration, TSMC-Online provides a variety of engineering capabilities, including interactive views of prototyping, lot status, yield analysis and quality reliability data. It is also empowered with design collaboration capabilities in support of customer access to important information needed during the design process. Aided by Design Service Alliance, to which we shall return later, TSMC-Online provides selected blocks of IP owned by third parties - these are robust design solutions that conform to TSMC's production technologies - which are then made available to designers.

For service coverage, TSMC-Direct is similar to TSMC-Online, but whilst the latter is open to wider access, since it is Internet-based, the former is a system-to-system and 
business-process-to-business-process information link that transmits and receives mission-critical information between the ERP systems of TSMC and its customers. TSMC-Direct acts as an extension of customers' own internal systems enabling collaborative planning, work in progress tracking, engineering data sharing, real-time order placement, confirmation and other important business control features.

Through the use of TSMC-YES, TSMC's customers can perform yield enhancement analysis remotely from their workstations or PCs using exactly the same tools, data and models as those employed by TSMC's engineers. This aims to promote engineering collaboration between TSMC and its customers in order to achieve shorter yield analysis cycles, improved yield enhancement efficiencies and faster ramp to production. In addition, TSMC-ILW and eJobView are specifically instrumental in design collaboration. TSMC-ILV is a real-time web-based distributed layout information viewing service providing an engineering collaboration platform for communicating on layout issues.

Through these means, designers can interactively review, navigate, highlight and discuss layout issues with TSMC's service engineers. As a result, it may be possible to achieve improved design productivity, lower engineering and debugging costs, and faster time-to-market.

TSMC's eJobView is a mask inspection software system - the first of its kind in the foundry industry - which allows external customers to view mask images anytime or anywhere through their favorite web browser. Foundry mask data sign-off previously involved several days of inspection and discussion, and even expensive air travel costs for international customers. In contrast, through the use of eJobView, mask image inspection is immediate, with remote teams now able to discuss critical projects in real time, leading to faster time to tape-out, lower development costs and faster time to volume. 
In order to facilitate design collaboration, TSMC has also formed a Design Service Alliance with third parties. As mentioned earlier, the emergence of SOC has highlighted the importance of SIPs, and as a result, IC design has come to resemble the assembly of SIPs, from both internal and external sources. Design houses are also faced with the challenge of choosing from amongst a variety of library suppliers and Electronic Design Aid (EDA) tools. TSMC previously functioned as a pure-play foundry with limited design service capacity, but with Design Service Alliance, the company can now mobilize external resources to facilitate the design processes of its customers.

Design Service Alliance encompasses the four service areas that make up the IC design process - third party libraries, silicon-verified IPs, experienced IC designers and proven EDA software. A network of leading third party library vendors form the core of the Library Alliance enabling TSMC's customers to gain access to required technical services, leading edge process-specific technologies and documents on design requirements. IP Alliance encompasses a large category of silicon-verified and production-proven foundry specific IPs, which are useful for designers in IP assembly.

Through the Design Center Alliance, TSMC helps its customers to connect to a global network of qualified and experienced IC design centers in order to gain the necessary design expertise. Similarly, through the EDA Alliance, TSMC's design service engineers work with EDA Alliance members in order to deliver TSMC-specific technology files and design kits that may simplify its customers' design experience. In essence, the Design Service Alliance as a whole aims to provide TSMC's customers with total IC design solutions to accelerate cycle time from specification, through tape-out, to finished wafers. Both TSMC's customers and the key testing and packaging firms can gain access to the Design Service Alliance using TSMC-Online as the platform. 
TSMC's customer services have also been extended to collaboration on prototyping through CyberShuttle. First launched in October 1998, CyberShuttle allows multiple customers to share the costs of a single mask set and prototype in a pilot run. It aims to help customers to reduce substantially their non-recurring engineering (NRE) charges for small wafer volume, providing fast and cost-effective prototyping. According to TSMC, Cybershuttle will launch 93 multi-project wafers during 2001, with the first half alone almost matching the 50 shuttles launched throughout the whole of last year.

To summarize, whilst starting out as a stand-alone OEM foundry, TSMC has come to resemble a provider of integrated service packages covering a wide range of value chain management activities thanks to its extensive application of e-commerce. Basically, through its arms-length relationship with its customers, TSMC is not just a pure manufacturer, it has become the natural place to verify the manufacturability of its customers' designs and to ensure the quality and timely delivery of their finished wafers. The ability of the electronic Internet and e-commerce links to accelerate and broaden information transfer between TSMC and its customers not only helps to simplify their tasks of knowledge management and exchange, but also induces TSMC to widen the scope of its extended supply chain management activities.

In a sense, the method of e-commerce employed by TSMC, or more specifically TSMC-Online, acts as a portal providing comprehensive support for its customers' major operational tasks, ranging from prototyping and design, to engineering and logistics. In terms of design, aided by its B2B Internet applications, TSMC has drawn on a portfolio of design solutions from third parties to help its customers to achieve better designs, more reliable design reuse and faster time-to-market, leading to virtual integration of a network of firms. 
In TSMC's B2B e-commerce model, goods and cash flows are secondary to information flows. As a pure-play foundry, its inventory costs for finished products are not an important issue, whereas in contrast, customer relationship management is regarded as central to TSMC's operations as a means of securing its rates of capacity utilization and profitability. In addition, from their own viewpoint, B2B e-commerce is essential in order for foundries to come to terms with the trend towards SOC. Therefore, TSMC's e-commerce initiatives aim to meet the across-the-broad needs of its customers, in order to enhance customer loyalty.

It is possible to identify the operational impact of TSMC's e-commerce, but its strategic significance has to be interpreted in a wider context of inter-firm relationships. In operational terms, TSMC was able to deliver WIP reports three times a day in 1998, whilst a Korean counterpart at that time managed to do this only once a week. Nowadays, TSMC's WIP reporting is real-time. In addition, thanks to e-commerce, order confirmation in TSMC can now be completed in two seconds, as compared to two days in the past. Furthermore, TSMC's e-commerce applications enable it to provide tailored packages for its customer that include design support, cell library, IP, quality/reliability as well as process technology and wafer capacity. As a result, its customers can 'virtually' own a foundry, providing a total solution, by leveraging TSMC's internal and external resources. In this way, TSMC has set the rules of the game for the industry, which dictate that foundry must go beyond manufacturing muscle to become an essential platform for its customers to gain access to across-the-board competencies. TSMC's case proves that e-commerce applications can be a fertile ground for building up this new comparative advantage. 


\section{Conclusions and Implications}

Taiwan's achievements in high-tech production can be better understood by the ability of local firms to leverage and align local and international networks. The industrial structures of the island's PC and IC sectors are both characterized by vertical disintegration but with strong linkages between local firms and across national borders. The agglomeration effect of industrial clusters helps to create the momentum for the development of local industries in Taiwan and, to the extent that the local networks become part of the global network, the local industries are given additional ammunition for development. More importantly, the use of IT has helped these Taiwanese firms to closely integrate themselves into the global production networks.

The two cases of Mitac and TSMC differ in a couple of aspects. Firstly, in the case of Mitac, the brand marketers, such as Compaq, took the initiative in shaping the global production network and in deploying IT integration within it. In contrast, TSMC appeared to play a more active role in this respect, since the company considered virtual integration as an evitable response to the emerging call for SOC. Secondly, in terms of inter-organizational and cross-border supply-chain integration, goods flows are no less important than information flows in the case of Mitac, and for the PC industry in general. However, for TSMC, such goods flows are secondary to information flows. This helps to explain why TSMC chose to take part in managing global production and knowledge networks, even though its production function is currently concentrated in Taiwan.

Nonetheless, the two organizations do have some things in common. First of all, both of the companies have evolved from stand-alone OEM manufacturers towards providers of integrated service packages encompassing a wider range of value-chain activities than manufacturing. By fine-tuning its international operations in a global logistics way and 
aided by IT application, Mitac has begun to shoulder service functions such as the coordination of cross-border supply chains and logistics. Similarly, TSMC exploits its unique position in the IC industry to act as a portal providing comprehensive support for its customers' major operational tasks, ranging from prototyping, design and engineering, to logistics. In so doing, both of them have become an essential node of their respective global production networks.

Of equal importance is the formation of the global production networks that have resulted in new rules of the games for the two industries, towards which, both Mitac and TSMC have contributed in part. Central to global logistics is the subcontractors' ability to weave together the cross-national constituent elements of the value chain into a competitively effective and rapidly responsive production and logistics system. Therefore, industrial competition within the PC industry relies not just on lower costs, but also on rapid response capabilities and flexibility. In the case of TSMC, emphasis is placed on the tailored services packages provided to its customers, which include design support, cell library, SIP, quality/reliability, as well as process technology and wafer capacity. TSMC has thus dictated the new rules of the game, that foundry must go beyond manufacturing muscle to become an essential platform for its customers to gain access to across-the-board competencies. In light of all these factors, the essence of IT application is to facilitate networked firms participating in setting the rules of the game for industrial competition, preferably in the international arena. 


\section{REFERENCES}

Angel, D.P. and J. Engstrom (1995), 'Manufacturing systems and technology change: The US personal computer industry', Economic Geography, Vol.71, No.1, pp.79-102.

Berryman, K. and S. Heck (2001), 'Is the third time the charm for B2B?', McKinsey Quarterly, special edition of online tactics, pp.18-22.

Borrus, M. and Z. Borrus (1997), 'Globalization with borders: The rise of Wintelism and the future of global competition', Industry and Innovation, Vol.4, No.2, pp.141-66.

Cantwell, J. and G.D. Santangelo (1999), 'The frontier of international technology networks: Sourcing abroad the most highly tacit capabilities', Information Economics and Policy, Vol.11, pp.101-123.

CEPD (2001), Global Logistics \& Case Study, Council for Economic Planning and Development: Taipei (in Chinese).

Chen, S.H. and D.N. Liu (1999), Strategic Alliances in the Context of Competition Policy, final report to the Industrial Development Bureau, Chung-Hua Institution for Economic Research: Taipei, (in Chinese).

Chen, S.H. and D.N. Liu (2000), 'Taiwan's active role in the global production network', in P. Chow and B. Gill (eds.), Weathering the Storm: Taiwan, Its Neighbors and the Asian Financial Crisis, Brookings Institution Press: Washington D.C.

Chen, S.H. and M.C. Liu (2000), 'The knowledge-based economy and information technology: The Taiwanese experience', paper presented at the ASEAN Roundtable 2000, New Development Paradigms in Southeast Asia: The Challenge of Information Technology, $12^{\text {th }}-13^{\text {th }}$ 
October, National University of Singapore.

Chen T.J., S.H. Chen and M.C. Liu (2000), 'Implications, challenges and prospects of the knowledge-based economy for Taiwan', paper presented at the Trends and Issues 2000 Workshop, $25^{\text {th }}-26^{\text {th }}$ October, Tokyo, Japan.

Chen T.J. and Y.H. Ku (2000), 'Offshore sourcing strategies of multinational firms in Taiwan', manuscripts, Department of Economics, National Taiwan University: Taipei.

Chen, T.J., S.H. Chen and M.C. Liu (2001), Implications, challenges and prospects for Taiwan in the knowledge-based economy, East-West Center Working Papers, Economics Series No.35, East-West Center: Honolulu.

Delapierre, M. and L.K. Mytelka (1998), 'Blurring boundaries: New inter-firm relationships and the emergence of networked knowledge-based oligopolies', in M.G. Colombo (ed.), The Changing Boundaries of the Firm: Explaining Evolving Inter-Firm Relations, Routledge: London and New York.

ERSO (2000), Almanac of the Semiconductor Industry in Taiwan, Industrial Technology Research Institute: Hsin-Chu.

Economist Intelligent Unit (2000), The E-business Value Chain: Winning Strategies in Seven Global Industries, Economist Intelligent Unit: New York.

Hakansson, H. (1987), Industrial Technological Development: A Network Approach, Croom Helm: London.

Hobday, M. (1995), Innovation in East Asia: The Challenge to Japan, Edward Elgar: Aldershot, UK. 
Jovanovic, B. and R. Rob (1989), 'The growth and diffusion of knowledge', Review of Economic Studies, Vol.56, No.4, pp.569-82.

Kawakami, M. (1996), Development of the Small and Medium-sized Manufacturers in Taiwan's PC Industry, CIER Discussion Paper Series 9606, Chung-Hua Institution for Economic Research: Taipei.

Kim, S. and N. Tunzelmann (1998), Aligning Internal and External Networks: Taiwan's Specialization in IT, SPRU, University of Sussex: Brighton.

Kotabe, M. (1989), 'Hollowing-out of US multinationals and their global competitiveness', Journal of Business Research, Vol.19, pp.1-15.

Kotabe, M. (1996), 'Global sourcing strategy in the Pacific: American and Japanese multinational companies', in G. Boyd (ed.), Structural Competitiveness in the Pacific, Edward Elgar: Cheltenham, UK.

Kraemer, K.L., et al. (1996), 'Entrepreneurship, flexibility and policy coordination: Taiwan's Computer Industry', The Information Society, Vol.12, pp.215-49.

Kraemer, K.L. et al. (2000), 'Refining and extending the business model with information technology: Dell Computer Corporation', The Information Society, Vol.16, pp.5-21.

Piore, M. and C. Sable (1984), The Second Industrial Divide, Basic Books: New York.

Rauch, J.E. (1999), 'Networks versus markets in international trade,' Journal of International Economics, Vol.48, pp. 7-35.

Saxenian, A. (1994), Regional Advantage, Harvard University Press: Cambridge, MA. and London. 
Saxenian, A. (1997), 'Transactional entrepreneurs and regional industrialization: The Silicon Valley-Hsinchu connection,' Paper presented at the Conference on Social Structure and Social Change: International Perspective on Business Firms and Economic Life, Academia Sinica, Taipei, Taiwan.

Schumpeter, J.A. (1942), Capitalism, Socialism and Democracy, Harper: New York.

Senker, J. and W. Faulkner (1993), 'Networks, tacit knowledge and innovation', paper presented at the Second International Conference on Advances in Sociological and Economic Analysis of Technology, April, UMIST: Manchester.

Sigurdson, J. (1990), 'The internationalization of R\&D - An interpretation of forces and responses', in J. Sigurdson (ed.), Measuring the Dynamics of Technological Change, Pinter: London.

Swanmidass, P. and M. Kotabe (1993), 'Component sourcing strategies of multinationals: An empirical study of European and Japanese multinationals', Journal of International Business Studies, Vol.24, No.1, pp.81-100.

TSMC (2001), Foundry Watch, TSMC: Hsinchu (www.tsmc.com).

Venkatesan, R. (1992), 'Strategic sourcing: To make or not to make', Harvard Business Review, (Nov-Dec), pp.98-107.

Windrum, P. (1999), The MERIT Report on Innovation Networks in E-commerce, prepared for the SEIN Work Package 4, EU TSER Programme.

Wise, R. and P. Baumgartner (1999), 'Going downstream: The new profit imperative in manufacturing', Harvard Business Review, September-October, pp.133-141. 
APPENDIX 
Figure 1 Disintegration of the IC Industry

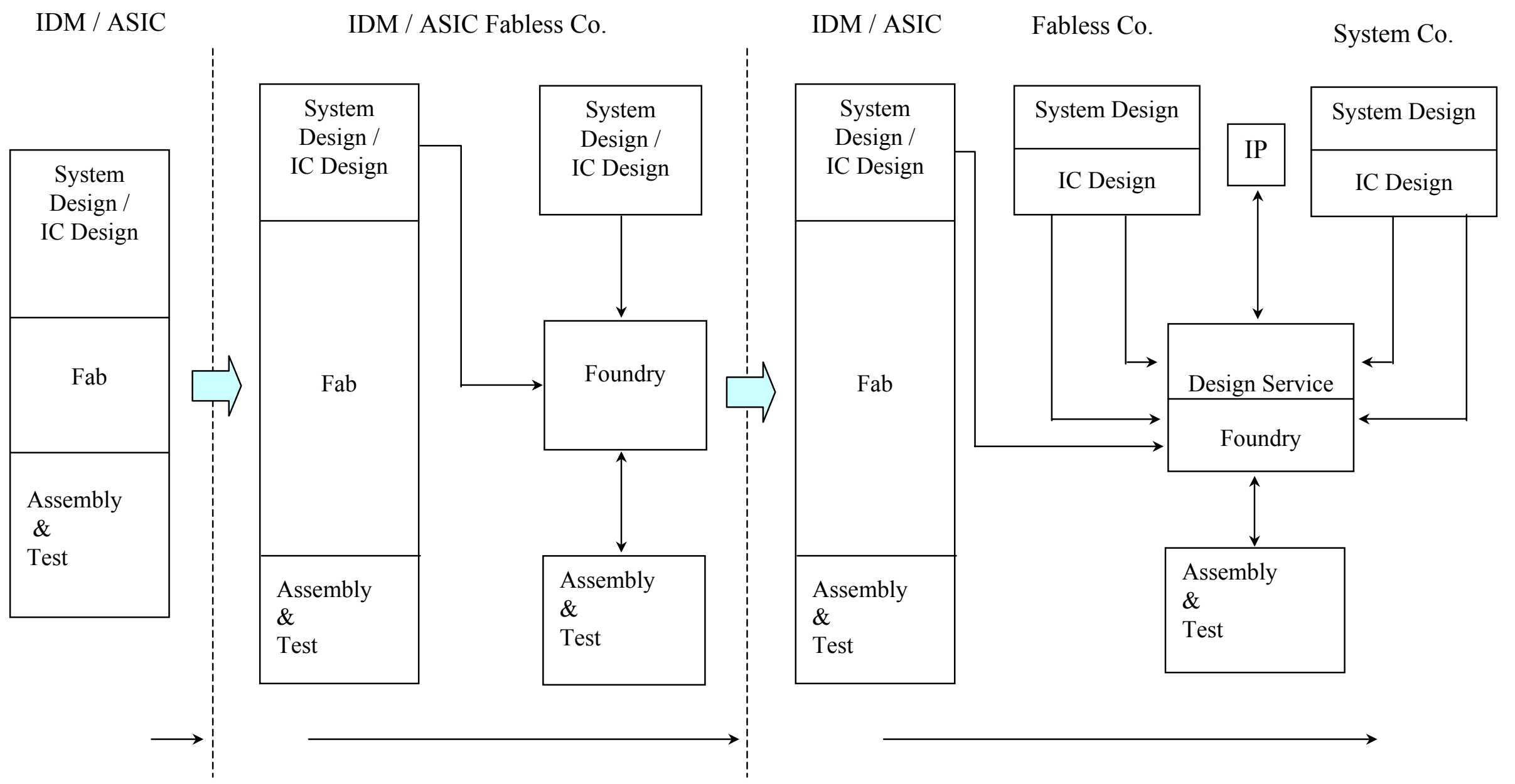




\section{Figure 2 Mitac's Global Logistics System}

Goods Flows

Information

Flows

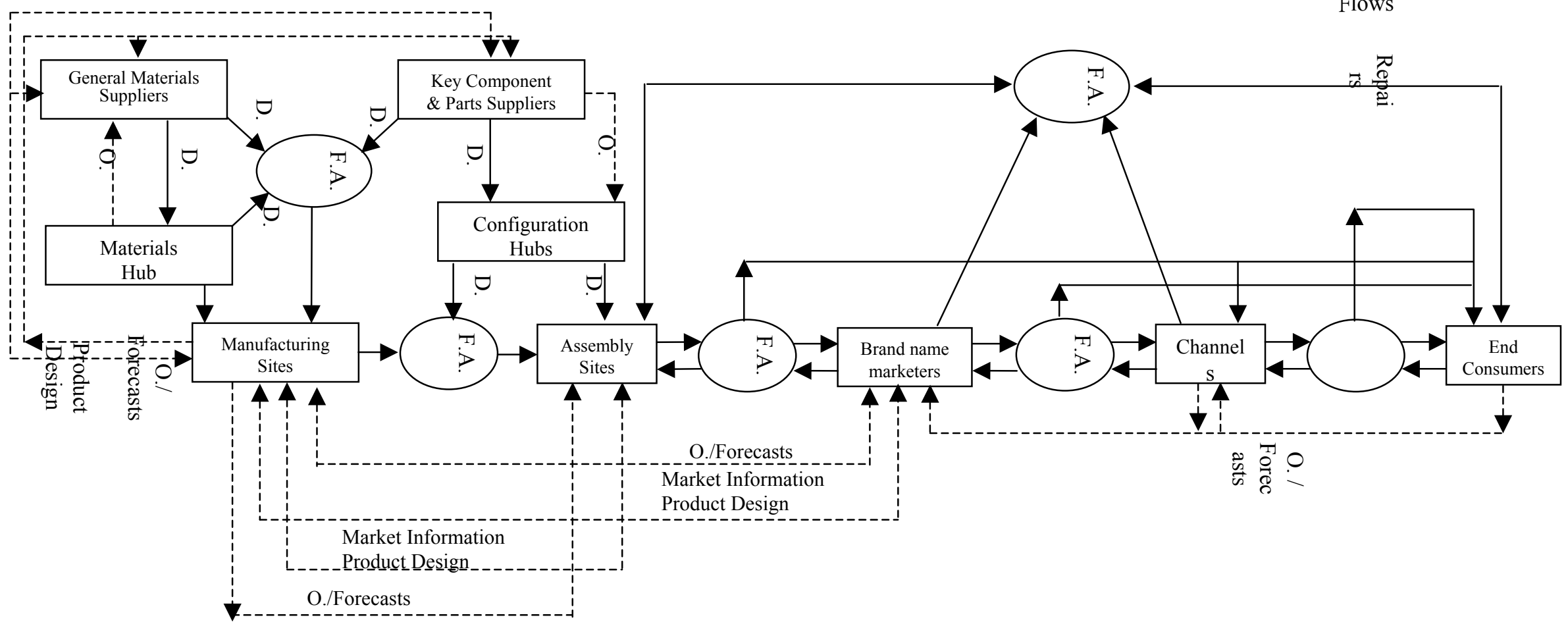

Source: Adapted from CEPD (2001), p.57.

$\mathrm{O}=$ Order; $\mathrm{D}=$ Delivery; F.A. $=$ Forwarding Agents 


\section{Figure 3 The Framework of TSMC's e-Business}

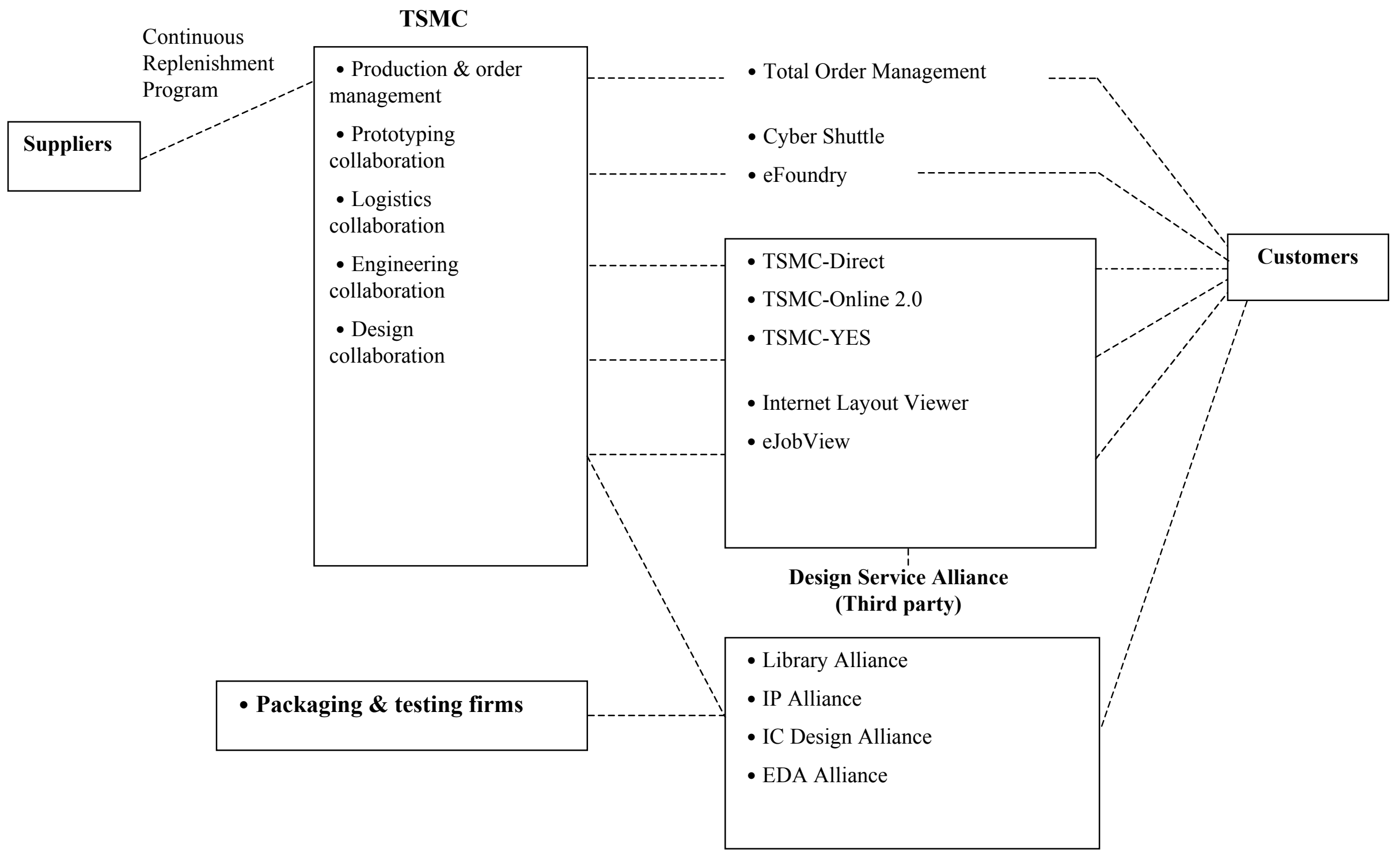

